\title{
Ring Chromosomes in Two Infants with Congenital Malformations*
}

\author{
MARIA A. VARELA and WILLIAM H. STERNBERG \\ From the Departments of Anatomy and Pathology, Tulane University School of Medicine, New Orleans, Louisiana, \\ 70112, and Charity Hospital of Louisiana at New Orleans, Louisiana, U.S.A.
}

Ring chromosomes in association with congenital malformations have previously been reported in approximately 26 patients. The ring chromosome was apparently derived from one of the $\mathrm{X}$ chromosomes in 6 patients (Lindsten and Tillinger, 1962; Lüers, Struck, and Nevinny-Stickel, 1963; Hustinx and Stoelinga, 1964; Bain, Gauld, and Farquhar, 1965; Pfeiffer and Büchner, 1965; Bishop et al., 1966), and was assigned to the A group in one instance (Gordon and Cooke, 1964), and to the B group in another (Rohde and Tompkins, 1965). Three examples of $\mathrm{C}$ group ring chromosomes (Smith-White et al., 1963; Atkins et al., 1966a); 8 of the D group (Wang et al., 1962; Bain and Gauld, 1963; Turner, 1963; Reisman, Darnell, and Murphy, 1965; Adams, 1965; Teplitz et al., 1967; Sparkes, Carrel, and Wright, 1967; Gerald et al., 1967), 4 of the E group (Wang et al., 1962; Genest, Leclerc, and Auger, 1963; Lucas et al., 1963; Gropp, Jussen, and Ofteringer, 1964), and one of the G group (Hoefnagel, Schroeder, and Benirschke, 1967) have been reported. Two other infants with ring autosomes of unknown origin have also been described (Fisher, 1965; Atkins, Sceery, and Kennan, 1966b).

This paper presents two examples of infants with ring chromosomes. In one instance the ring chromosome replaces a chromosome of the D group (13-15); the other is a mosaic with one line consisting of normal 46,XY plus a ring chromosome of unknown derivation. The latter case is rare, since, to our knowledge, only one other instance of a trisomic state in which one of the chromosomes is a ring has been reported (Atkins et al., 1966b).

\section{Case Reports}

Case 1. This Negro female infant was born at term to a 29-year-old woman who had three other apparently

\footnotetext{
* Supported in part by Grant No. 5RO 1 HD $0062-03$ from the National Institute of Child Health and Human Development and by a grant of The National Foundation-March of Dimes.

Received August 5, 1968.
}

normal children. Her pregnancy was complicated by hypertension. No history of consanguinity or irradiation was obtained. Birthweight $2268 \mathrm{~g}$., length $45 \mathrm{~cm}$., head circumference $29 \mathrm{~cm}$., chest circumference $28 \mathrm{~cm}$. At birth the infant failed to breathe for approximately 2 . minutes, but responded to routine resuscitation procedures. A systolic murmur grade $2 / 4$ was audible at the apex. The ears were noted to be low set with large pinnae. 'Cafe au lait' spots were noted over the back and ankles. The rest of the physical examination was non-contributory.

When she was 15 months old she was readmitted because of respiratory distress. At this time she weighed $4648 \mathrm{~g}$., her height was $61 \mathrm{~cm}$., and head circum ference $37 \cdot 2 \mathrm{~cm}$. (Fig. 1). According to the mother the

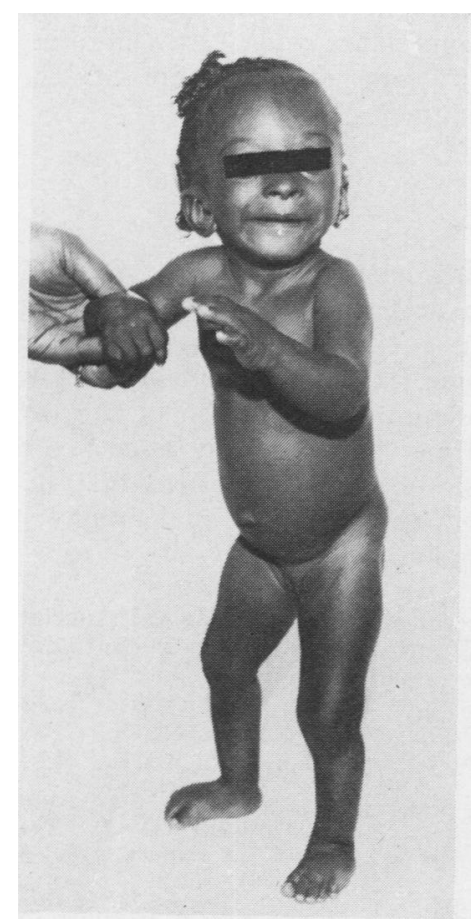

FIg. 1. Case 1 at 15 months, weight 4648 g., height $61 \cdot 0 \mathrm{~cm}$. Note small stature, alert expression, and low-set ears. 
infant suffered from repeated colds and had had bilateral pneumonia at age 5 months. She was thought to be mentally retarded. Pneumonia was diagnosed clinically and radiologically. She was treated with antibiotics and discharged asymptomatic.

Several days later she again developed acute respiratory distress and was rushed to the hospital where she was pronounced dead on arrival.

Pertinent necropsy findings were as follows: the heart weighed $78 \mathrm{~g}$. There was marked right ventricular hypertrophy and dilatation. The right ventricular wall measured $0.6 \mathrm{~cm}$. in thickness compared to the left ventricular thickness of $0.4 \mathrm{~cm}$. An interventricular septal defect was present in an unusual location, high in the posterior portion of the interventricular septum, $1 \mathrm{~cm}$. from the posterior wall of the left ventricle and $1 \mathrm{~cm}$. below the aortic cusps; it was roughly triangular in shape and measured $3 \mathrm{~cm}$. in greatest diameter. Also present was an interatrial septal defect of the ostium primum type. This measured $0.8 \mathrm{~cm}$. in diameter. The right atrium was also moderately dilated. The valves showed no abnormalities.

The lungs together weighed $110 \mathrm{~g}$., and showed severe chronic passive congestion and oedema. The intrinsic pulmonary arteries in some sections of lung showed intimal thickening with fibrosis and accumulations of lipophages in the intima. Acute and chronic bronchitis and bronchiolitis were also present. The larynx and epiglottis were hyperaemic and oedematous. The liver weighed $220 \mathrm{~g}$. and showed moderate chronic passive congestion. The spleen, pancreas, kidneys, and gastro-intestinal tract were not remarkable.

Microscopical examination of the ovaries showed a moderate reduction of primordial follicles compared to that usually seen in ovaries of this age-group. An unusual finding was bilateral hypertrophy of the adrenal medullae. The medullary tissue was estimated to be at least three times as great as that normally seen in this age-group. The adrenal cortex was not unusual.

Cytogenetic studies. During life, chromosomes were studied on three peripheral leucocyte cultures and on a culture of skin fibroblasts (Fig. 2). The results are shown in Table I.

TABLE I

CHROMOSOME COUNTS OBTAINED FROM CELLS OF CASE 1

\begin{tabular}{l|c|r|r|r|r|r|r|r}
\hline $\begin{array}{l}\text { Examina- } \\
\text { tion }\end{array}$ & $<44$ & 45 & $45 \mathrm{R}$ & $46 \mathrm{R}$ & $\mathbf{4 7 R}$ & 92 & $\begin{array}{c}\text { Total } \\
\text { Cells } \\
\text { Counted }\end{array}$ & $\begin{array}{c}\text { No. of } \\
\text { Karyo- } \\
\text { types } \\
\text { Studied }\end{array}$ \\
\hline $\begin{array}{l}\text { Blood 1 } \\
\text { Blood 2 }\end{array}$ & 4 & 1 & 24 & 108 & 1 & 2 & 140 & 13 \\
Blood 3 & 1 & 0 & 8 & 137 & 0 & 1 & 143 & 16 \\
Skin & 2 & 2 & 7 & 138 & 0 & 1 & 150 & 12 \\
\hline
\end{tabular}

A ring chromosome was present in all cells with a count of 46 chromosomes but was variable in shape and size, resembling a figure eight in some metaphases, a doughnut in others, and interlocked circles in some others (Fig. 3). In the cells containing a ring, only 5 morphologically normal large acrocentrics were found. Metaphases with only 45 chromosomes including a ring were found to be broken cells with a random loss of a chromosome. Only 3 metaphase plates were found in which the ring appeared to be the lost chromosome. No cells with two rings were observed.

Buccal smears were positive for sex chromatin. The mother's chromosome study revealed a normal $46, \mathrm{XX}$ pattern. The father did not consent to chromosome studies.

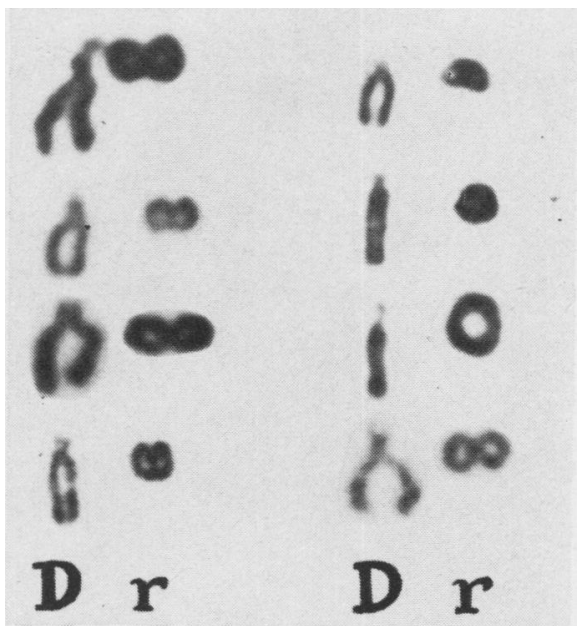

Fig. 3. One $\mathrm{D}$ group chromosome and the ring chromosome from each of 8 karyotypes from Case 1. Note that there is considerable variation in the size and shape of the ring in different cells. Satellite association is shown between the large acrocentric chromosome and the ring chromosome at the top of the first column; these two chromosomes are shown in the same relation that they bore to each other in the metaphase plate, and this association is seen at the point where the chromosomes appear to be in contact.

Dermatoglyphs. Analyses of the hand and sole prints, kindly performed by Dr. H. Warner Kloepfer, are expressed in the following formulations:

$$
\begin{aligned}
& \text { Palms: } \\
& \text { Rt. 9.7.5'1.O.A } \text {. O.O.O.L } 30: 34: 32 \\
& \text { 7.5.12 } \\
& \text { Lt. } \quad \text { 7.5.3.1.t.L } \text {. O.O.O.L } \quad 37-29.34 \quad 3.13 .0 .20 \\
& \text { Soles: } \\
& \text { Rt. } \quad L^{d} \cdot L^{p} \cdot K^{p} \cdot L^{p} \\
& \text { Lt. } L^{d} \cdot L^{p} \cdot L^{p} \cdot L^{p}
\end{aligned}
$$

Ulnar loops were found on all digits except the thumb which had a whorl on each hand.

Case 2. This male Negro infant was born to a 27 year-old mother, para 4, gravida 4. There was no history of consanguinity or irradiation. The father's age was 21 . Gestation time 7 months, and birthweight $1785 \mathrm{~g}$. General condition at birth appeared good but various anomalies were noted. The ears were low set and large, with pendulous lobes and a pre-auricular 


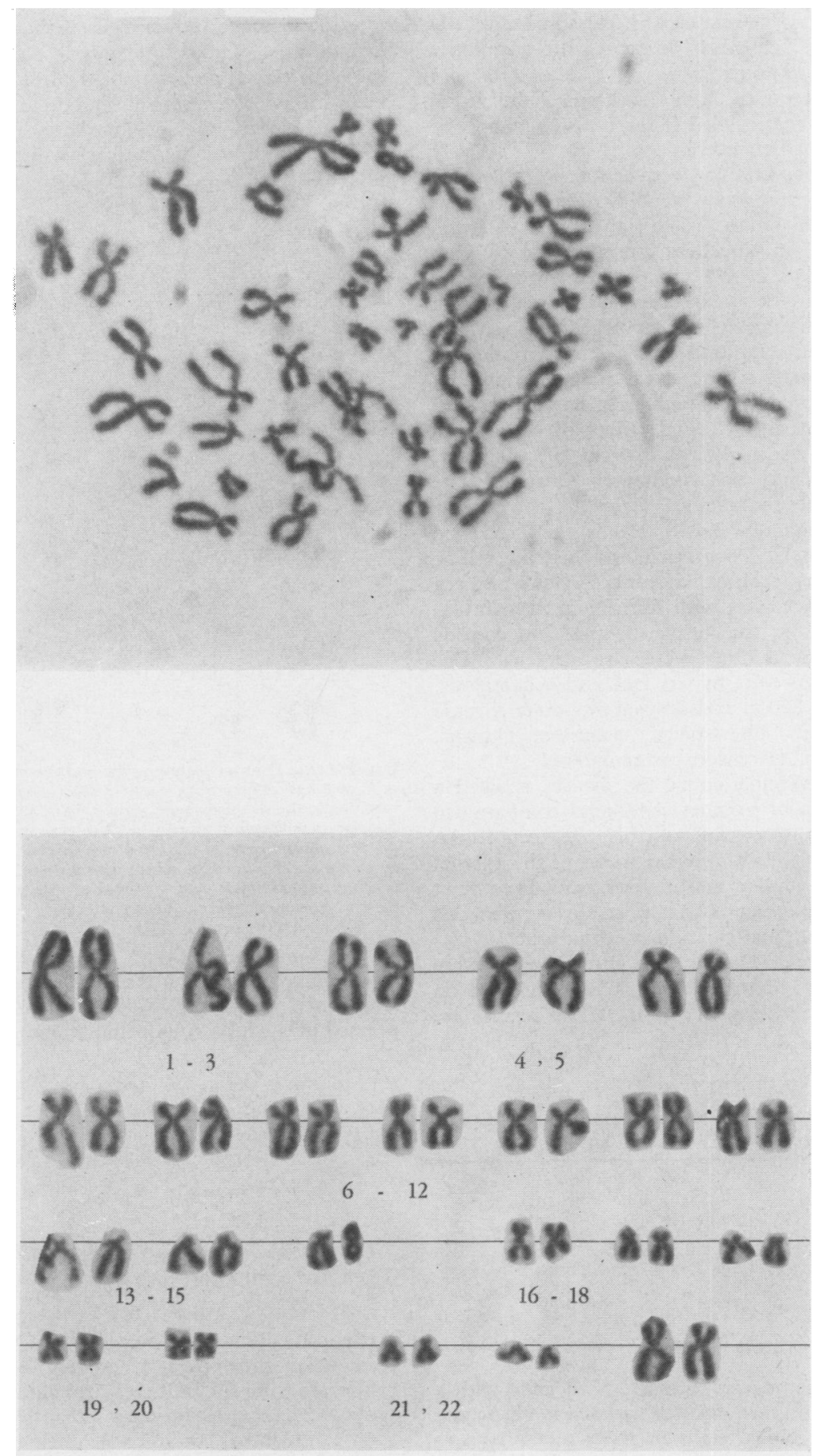

Fig. 2. Metaphase plate and karyotype from skin fibroblast culture in Case 1 showing the ring in the 13-15 group. The two X chromosomes in the lower line at the extreme right are not labelled. 


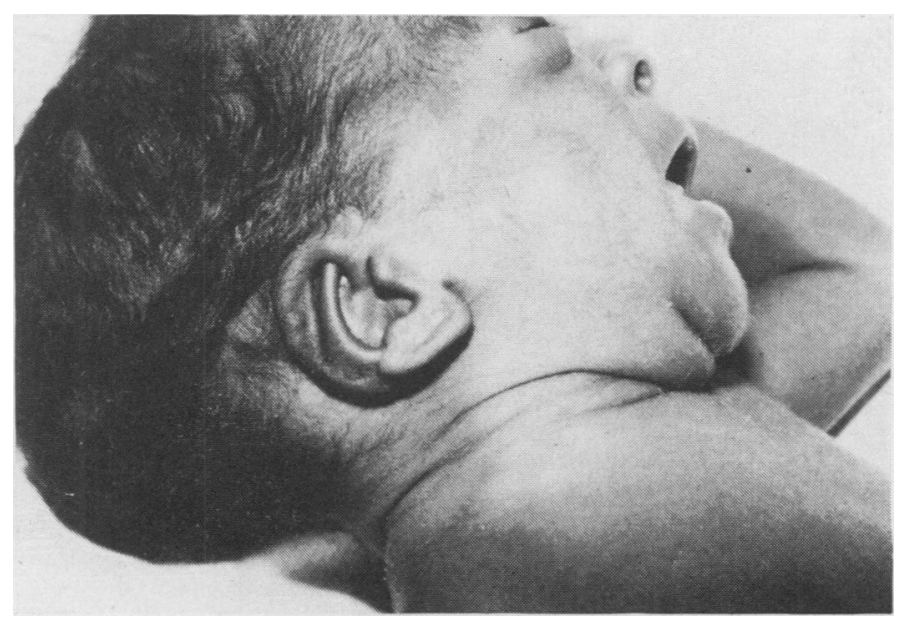

Fig. 4. Case 2 at age 3 months. Note abnormal ear lobes.

sinus on the left side (Fig. 4). Micrognathia and hypertelorism were noted, and the feet had a rockerbottom appearance. There were 5 nipples: 3 in the left and 2 in the right mammillary line. The right testicle was undescended, and a grade I hypospadias was present.

At the age of 5 weeks a harsh systolic murmur grade 4 was noted; the heart rate was $200 / \mathrm{min}$; and clinical diagnosis of pulmonary stenosis was made.

At the age of 3 months development and progress were considered excellent. The baby's weight at this time was $4280 \mathrm{~g}$., height $56.2 \mathrm{~cm}$., head circumference 39.2 $\mathrm{cm}$. ; chest circumference $34.5 \mathrm{~cm}$. (Fig. 5). However,

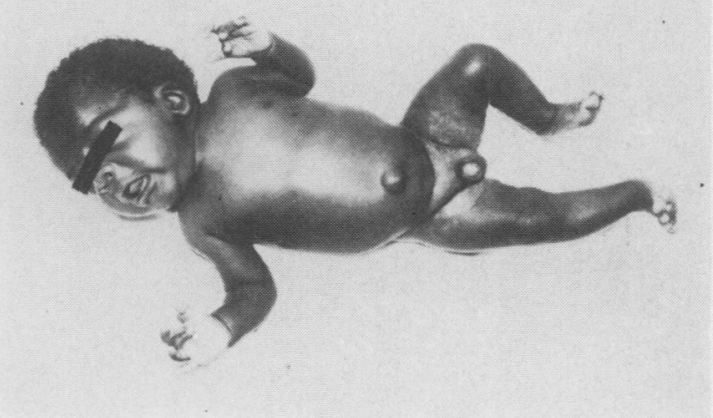

Fig. 5. Case 2 same age. Note accessory nipples, two on the left and one on the right, hypertelorism, and micrognathia. An umbilical hernia is also present.

ocular hypertelorism was conspicuous and a left divergent strabismus was noted.

Cytogenetic Studies. The patient's buccal smear was chromatin negative.

Two cultures of peripheral leucocytes for chromosome studies were done at the ages of 9 days and 32 days. Fibroblasts were cultured from a skin biopsy specimen obtained at age 3 months.

Both blood and skin studies showed mosaicism, with a cell line having 47 chromosomes including a ring (Fig. 6), and another cell line with 46 chromosomes (Fig. 7). The chromosome counts are shown in Table II. No

TABLE II

CHROMOSOME COUNTS OBTAINED FROM CELLS OF CASE 2

\begin{tabular}{|c|c|c|c|c|c|c|c|c|}
\hline $\begin{array}{c}\text { Examina- } \\
\text { tion }\end{array}$ & $<46$ & $46 R$ & 46 & 47R & 92 & $<92$ & $\begin{array}{c}\text { Total } \\
\text { Cells } \\
\text { Counted }\end{array}$ & $\begin{array}{l}\text { No. of } \\
\text { Karyo- } \\
\text { types } \\
\text { Studied }\end{array}$ \\
\hline $\begin{array}{l}\text { Blood } 1 \\
\text { Blood } 2 \\
\text { Skin }\end{array}$ & $\begin{array}{r}16 \\
7 \\
2\end{array}$ & $\begin{array}{l}2 \\
0 \\
1\end{array}$ & $\begin{array}{l}59 \\
54 \\
46\end{array}$ & $\begin{array}{l}23 \\
29 \\
32\end{array}$ & $\begin{array}{l}0 \\
0 \\
2\end{array}$ & $\begin{array}{l}1 \\
0 \\
0\end{array}$ & $\begin{array}{r}101 \\
90 \\
83\end{array}$ & $\begin{array}{l}13 \\
11 \\
13\end{array}$ \\
\hline
\end{tabular}

significant difference in the percentage of cells with a ring was found in either of the blood studies or in the fibroblast culture studies. The ring chromosome showed variation in shape and size. It appeared very rarely as a perfect ring and more often resembled a figure eight stained intensely throughout. Its size in most metaphases was comparable to the chromosomes of group F (19-20) (Fig. 8). Metaphase plates with a count of 46 including a ring chromosome, and those with less than 46 with no identifiable ring, were found to be broken cells with a random loss of a chromosome. No cells with two rings were detected.

Chromosome studies on cultures of peripheral blood leucocytes of the patient's mother showed a normal female complement. The infant's father was not available for study.

Dermatoglyphs. Patterns were analysed by Dr. $\mathrm{H}$. Warner Kloepfer.

Palms:

$$
\begin{array}{llllll}
\text { Rt. } & 7(8) & .5^{\prime \prime} & (6) & 5^{\prime} 1 . t . L^{r} & \text { O.O.O.L } \\
\text { Lt. } & 7.5^{\prime \prime} & .3^{\text {h }} & \text {.2.t.Lr. L/O.O.L }
\end{array}
$$




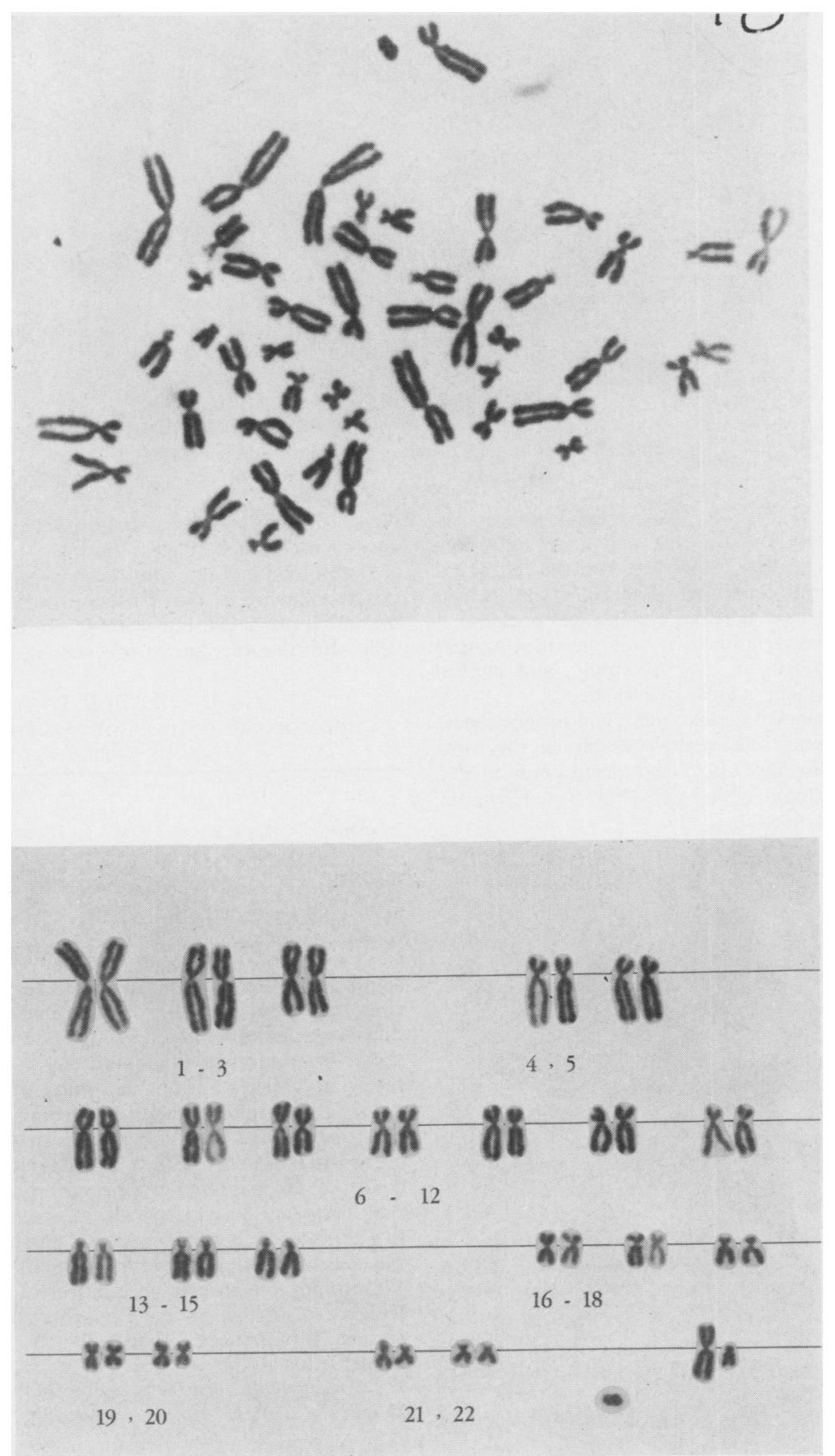

Fig. 6. Metaphase plate and karyotype from skin fibroblast culture of Case 2. The $\mathrm{X}$ and $\mathrm{Y}$ chromosomes are not labelled. The ring is shown at bottom right. This represents a cell from one of the two cell lines in this mosaic. 


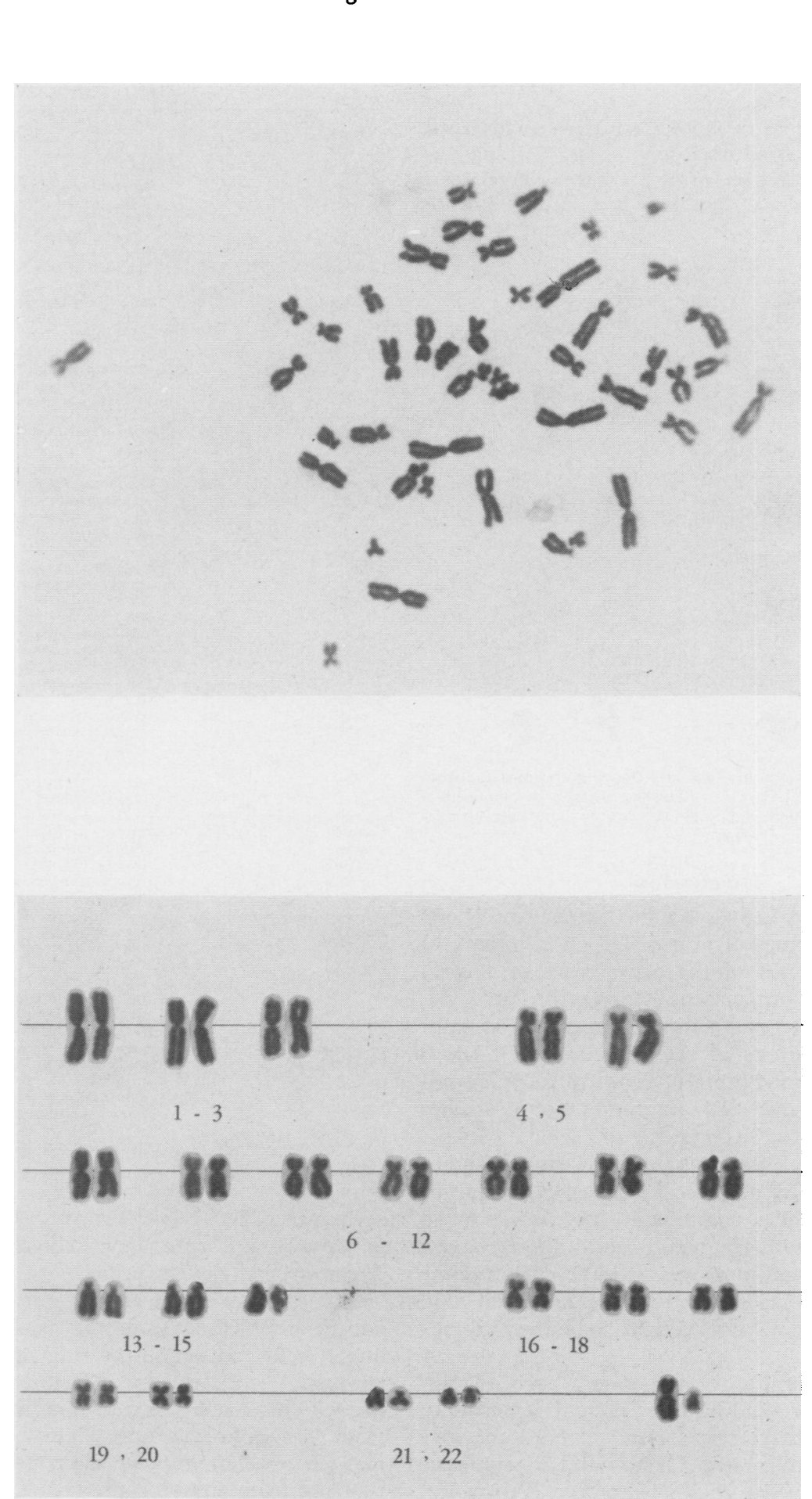

Fig. 7. Case 2: Normal male metaphase plate and karyotype representing the second cell line in the mosaic. The $\mathrm{X}$ and $\mathrm{Y}$ chromosomes are not labelled. 
Soles:

Rt. $L^{p} \cdot$ O.O. $L^{d}$

Lt. L $^{\mathrm{p}}$ O. L $^{\mathrm{d}} \cdot \mathrm{L}^{\mathrm{d}}$

Among the 6 digits in which the pattern could be determined, there was an ulnar loop on digits 1 and 3 of the right hand and 1 and 4 of the left. There was a whorl on digit 4 of the right hand and on digit 3 of the left.

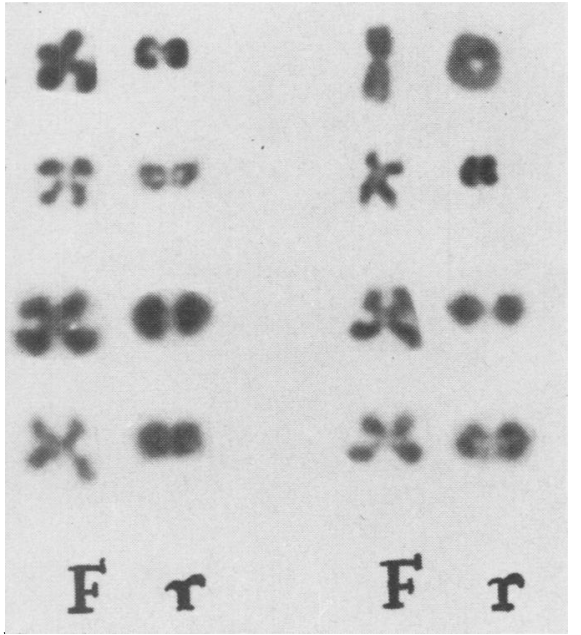

Fig. 8. An F group chromosome and the ring chromosome from each of 8 karyotypes of Case 2. The selection of a chromosome of the F group was a random choice and serves only to indicate the relative size of the ring.

\section{Discussion}

In Case 1 there is little doubt that the ring is one of the chromosomes of Group D. A summary of the clinical features of the other cases of ring D reported and of our patient is given in Table III. It is now possible with autoradiography to attempt to separate members of the $\mathrm{D}$ group. Of the 8 cases reported in the literature with ring D chromosomes only 2 have had autoradiographic studies (Sparkes et al., 1967; Gerald et al., 1967). In the case reported by Sparkes et al., the ring chromosome was identified as $\mathrm{D}_{2}$. The absence of thumbs and other anomalies common to his case and two others (Adams, 1965; Bain and Gauld, 1963) suggest that the ring chromosome was also a $\mathrm{D}_{2}$ chromosome in the latter two cases. In the case of Gerald et al. the $\mathrm{D}_{1}$ chromosome was thought to be the chromosome affected.

Episodes of repiratory infections, 'cafe au lait' spots, low-set protruding ears, mental retardation, and failure to thrive were found in both the case reported by Teplitz et al. (1967) and in our case. In the cases of Wang et al. (1962) and Reisman et al. (1965) somewhat similar findings were noted, though 'cafe au lait' spots and respiratory infections
TABLE III

SUMMARY OF CLINICAL FEATURES IN PATIENTS WITH A RING D

\begin{tabular}{|c|c|c|c|}
\hline Authors & Sex & Age & Clinical Features \\
\hline $\begin{array}{l}\text { Wang et al. } \\
\quad(1962)\end{array}$ & $\mathbf{M}$ & $\begin{array}{c}5 \\
\text { mth. }\end{array}$ & $\begin{array}{l}\text { Failure to thrive, odd facies, large ab- } \\
\text { normal ears, small mandible, epican- } \\
\text { thic folds, inguinal and umbilical } \\
\text { hernias, high-arched palate, simian } \\
\text { crease, mental retardation }\end{array}$ \\
\hline $\begin{array}{l}\text { Bain and } \\
\text { Gauld } \\
(1963)\end{array}$ & $\mathbf{F}$ & $\begin{array}{l}\text { Still- } \\
\text { born }\end{array}$ & $\begin{array}{l}\text { Absence of rt. thumb, rudimentary } \\
\text { thumb on lt., talipes equinovarus, } \\
\text { short hallux, fusion of } 4 \text { th and 5th } \\
\text { toes, simian creases, bilateral micro- } \\
\text { phthalmus, ant. defect of falx cerebri, } \\
\text { fusion of cerebral hemispheres, arrhi- } \\
\text { nencephaly, interventricular defect, } \\
\text { overriding aorta, hypoplastic kidneys, } \\
\text { bicornuate uterus }\end{array}$ \\
\hline $\begin{array}{l}\text { Turner } \\
(1963)\end{array}$ & $\mathbf{F}$ & $\begin{array}{l}30 \\
\text { yr. }\end{array}$ & $\begin{array}{l}\text { Short stature, moderate mental retarda- } \\
\text { tion }\end{array}$ \\
\hline $\begin{array}{l}\text { Reisman } \\
\quad \text { et al. } \\
\quad(1965)\end{array}$ & $\mathbf{M}$ & $\begin{array}{c}20 \\
\text { mth. }\end{array}$ & $\begin{array}{l}\text { Odd facies, large abnormal ears, diffuse } \\
\text { eczematoid rash, hypospadias, bi- } \\
\text { lateral undescended testes, mental } \\
\text { retardation }\end{array}$ \\
\hline $\begin{array}{l}\text { Teplitz } \\
\quad \text { et al. } \\
\quad \text { (1967) }\end{array}$ & $\mathbf{M}$ & $\begin{array}{l}2 \frac{1}{2} \\
\text { yr. }\end{array}$ & $\begin{array}{l}\text { Numerous episodes of pneumonia and } \\
\text { upper respiratory infections since } \\
\text { birth, failure to thrive, low-set and } \\
\text { protruding ears, high-arched palate, } \\
\text { 'cafe au lait' spots over chest, small } \\
\text { genitalia, hypospadias, mental and } \\
\text { motor retardation }\end{array}$ \\
\hline $\begin{array}{l}\text { Sparkes } \\
\quad \text { et al. } \\
\quad(1967)\end{array}$ & $M$ & $\begin{array}{c}5 \\
\text { yr. }\end{array}$ & $\begin{array}{l}\text { Mental and physical retardation, im- } \\
\text { perforate anus, hypospadias, trigono- } \\
\text { cephaly, abnormal ears, colobomata of } \\
\text { irides, epicanthal folds, micrognathiag } \\
\text { systolic murmur, ambiguous genitalia } \\
\text { absent thumbs, syndactyly of second } \\
\text { and third toes }\end{array}$ \\
\hline $\begin{array}{l}\text { Gerald } \\
\quad \text { et al. } \\
\quad(1967)\end{array}$ & $\mathbf{M}$ & $\begin{array}{c}5 \\
\text { yr. }\end{array}$ & $\begin{array}{l}\text { Systolic murmur, microcephaly, plang } \\
\text { valgus deformity of both feet, peculiar } \\
\text { overriding toes, mental and growth } \\
\text { retardation, anomalous inheritance of } \\
\text { haptoglobin type }\end{array}$ \\
\hline $\begin{array}{l}\text { Adams } \\
\quad(1965)\end{array}$ & $\mathbf{F}$ & $?$ & $\begin{array}{l}\text { Microcephaly, holoprosencephaly, hy- } \\
\text { pertelorism, ptosis of eyelids, epican- } \\
\text { thal folds, malrotated rt. pinna, } \\
\text { micrognathia, hypoplastic lt. nipple, } \\
\text { interventricular septal defect, con- } \\
\text { genital hip dysplasia, aplasia of thumbs, } \\
\text { failure to thrive }\end{array}$ \\
\hline Present case & $\mathbf{F}$ & $\begin{array}{c}15 \\
\text { mth. }\end{array}$ & $\begin{array}{l}\text { Failure to thrive, low-set ears with large } \\
\text { pinnae, 'cafe au lait' spots over back } \\
\text { and ankles, frequent respiratory in- } \\
\text { fections, interventricular and inter- } \\
\text { atrial defect, bilateral hypertrophy of } \\
\text { adrenal medullae }\end{array}$ \\
\hline
\end{tabular}

are not recorded. In contrast to these 4 cases other patients with $\mathrm{D}$ rings have shown gross malformations, especially of the limbs.

The identity of the ring in our second case cannot be established from the available data. The line of cells containing the ring represents a partial trisomy. Since the buccal smears were negative for sex chromatin the ring is probably not derived from the $\mathrm{X}$ chromosome. The congenital malformations present indicate a probable derivation of the ring from an autosome rather than from the $Y$ chromosome, since the XYY syndrome is usually accompanied by a more nearly normal phenotype. 
Size of the ring chromosome itself cannot be used for identification, since the amount of chromosomal deletion associated with the formation of the ring chromosome is unknown. Comparison of the phenotype with that of other known trisomies might be useful, but in this case the findings include stigmata reminiscent of both the D and E trisomy syndromes. Furthermore, the presence of mosaicism makes comparisons still more difficult. No conclusion concerning the identity of the ring can be reached on clinical grounds.

The cytogenetic findings in our second case can be explained in several ways. If the abnormality were entirely postzygotic two errors could explain trisomy, ring formation, and mosaicism. Nondisjunction in a division following the zygotic cleavage could give rise to mosaicism with a normal cell or cells, a trisomic cell, and a cell which, lacking an autosome, would presumably therefore disappear: ring formation would then occur in one of the trisomic chromosomes. If abnormal gametogenesis is involved, three errors must be postulated: nondisjunction in a gamete to give rise to a trisomic zygote, ring formation in one of the trisomic chromosomes occurring either in the gamete or postzygotically, and mosaicism which must of course be postzygotic. In this latter explanation the order of the first two errors can be reversed, resulting in what seems the most likely sequence of events: ring formation $\rightarrow$ non-disjunction $\rightarrow$ postzygotic loss of the ring in some cells.

In the case reported by Atkins and collaborators, instability of the ring, with progressive loss of the ring, was observed in repeated chromosome studies over a period of 13 months and also in prolonged fibroblast cultures. No tendency to ring loss has been demonstrated in prolonged fibroblast cultures of the skin of our patient. A recent chromosome study of peripheral blood leucocytes at the age of 18 months indicated no significant difference in the percentage of cells containing the ring.

\section{Summary}

Two unrelated infants with multiple congenital malformations and ring chromosomes in peripheral leucocyte cultures and skin fibroblast cultures are reported. The first patient, a Negro female, who died at the age of 15 months, had failed to thrive since birth. She had low-set ears, repeated respiratory infections, 'cafe au lait' spots, and congenital heart defects. The chromosome complement was 46 , with a ring replacing one of the chromosomes of the D group (13-15). Eight other cases of patients with ring $\mathrm{D}$ chromosomes are reviewed.

The second infant had abnormal ear lobes, polythelia, unilateral cryptorchidism, micrognathia, hypertelorism, and congenital heart disease. This patient showed $46 / 47$ mosaicism, with an extra chromosome which was a ring of unknown derivation.

We wish to express our indebtedness to Dr. Norman C. Woody for referring Case 2 to us, to Dr. H. Warner Kloepfer for making the dermatoglyphic analyses, and to Miss Elizabeth Earely for carrying out the tissue cultures on these cases.

\section{REFERENCES}

Adams, M. S. (1965). Palm-prints and a ring-D chromosome. Lancet, 2, 494.

Atkins, L., Pant, S., Hazard, G. W., and Ouelpette, E. M. (1966a). Two cases with a C-group ring autosome. Ann. Hum. Genet., 30, 1 .

, Sceery, R. T., and Keenan, M. E. (1966b). An unstable ring chromosome in a female infant with hypotonia, seizures, and retarded development. F. med. Genet., 3, 134.

Bain, A. D., and Gauld, I. K. (1963). Multiple congenital abnormalities associated with ring chromosome. Lancet, $2,304$.

, - , and Farquhar, J. W. (1965). A ring X chromosome in dwarfism. ibid., 1, 820.

Bishop, A. M., Blank, C. E., Simpson, K., and Dewhurst, C. J. (1966). An XO/X ring $\mathrm{X}$ chromosome mosaicism in an individual with normal secondary sexual development. $\mathcal{f}$. med. Genet., $3,125$.

Fisher, G. W. (1965). Ring chromosome mosaicism in a severely subnormal child with multiple congenital malformations. F. ment. Defic. Res., 9, 39.

Genest, P., Leclerc, R., and Auger, C. (1963). Ring chromosome and partial translocation in the same cell. Lancet, $1,1426$.

Gerald, P. S., Warner, S., Singer, J. D., Corcoran, P. A., and Umansky, I. (1967). A ring D. chromosome and anomalous inheritance of haptoglobin type. F. Pediat., 70, 172.

Gordon, R. R., and Cooke, P. (1964). Ring-1 chromosome and microcephalic dwarfism. Lancet, 2, 1212.

Gropp, A., Jussen, A., and Ofteringer, K. (1964). Multiple congenital anomalies associated with a partially ring-shaped chromosome probably derived from chromosome No. 18 in man. Nature (Lond.), 202, 829.

Hoefnagel, D., Schroeder, T. M., and Benirschke, K. (1967). A child with a group-G chromosome. Hum. Genet., 4, 52.

Hustinx, T. W., and Stoelinga, G. B. (1964). A ring-X-chromosome in part of the somatic cells of a patient with some characteristics of the Turner syndrome. Genetica, 35, 1.

Lindsten, J., and Tillinger, K.-G. (1962). Self-perpetuating ring chromosome in a patient with gonodal dygenesis. Lancet, $1,593$.

Lucas, M., Kemp, N. H., Ellis, J. R., and Marshall, R. (1963). A small autosomal ring chromosome in a female infant with congenital malformations. Ann. hum. Genet., 27, 189.

Lüers, T., Struck, E., and Nevinny-Stickel, J. (1963). Self-perpetuating ring chromosome in gonadal dysgenesis. Lancet, 2, 887.

Pfeiffer, R. A., and Büchner, T. (1965). Absence of late replication of a human X-ring chromosome. Nature (Lond.), 204, 804.

Reisman, L. E., Darnell, A., and Murphy, J. W. (1965). Abnormalities with ring chromosome. Lancet, $2,445$.

Rohde, R. A., and Tompkins, R. (1965). 'Cri du chat' due to a ring-B (5) chromosome. ibid., 2, 1075.

Smith-White, S., Peacock, W. J., Turner, B., and Den Dulk, G. M (1963). A ring chromosome in man. Nature (Lond.), 197, 102.

Sparkes, R. S., Carrel, R. E., and Wright, S. W. (1967). Absent thumbs with a ring $\mathrm{D} 2$ chromosome: A new deletion syndrome. Amer. F. hum. Genet., 19, 644.

Teplitz, R. L., Miller, D., Hansson, K. M., and Rundall, T. S. (1967). A human ring D chromosome associated with multiple congenital abnormalities. f. Pediat., 70, 936.

Turner, B. (1963). Cytogenetic studies in mental retardation. Proc. Aust. Assn. Neurol., 1, 41.

Wang, H. C., Melnyk, J., McDonald, L. T., Uchida, I. A., Carr, D. H., and Goldberg, B. (1962). Ring chromosomes in human beings. Nature (Lond.), 195, 733. 